\title{
Sons of Our Empire: Shifting Ideas of 'Race' and the Cinematic Representation of Imperial Troops in World War I
}

\author{
Toby Haggith and Richard Smith
}

During Queen Victoria's Diamond Jubilee in 1897, the Illustrated London News observed the 'curious medley of soldiery representing various races of men, African, Asian, Polynesian, Australasian, and American' from all over the British empire, gathered at Chelsea barracks to take part in the ceremonies. ${ }^{1}$ At the height of the imperial era the British empire was recruiting on five continents to fill the ranks of local militias, garrison troops and expeditionary armies. The multiethnic composition of the British army was inextricably linked to colonialism and the imperial project. Prior to colonial expansion, Ireland, Scotland and Wales had been traditional recruiting grounds. From the 1650 s African slaves and free blacks were deployed during the conflicts with France and Spain in the Caribbean. By the mid-eighteenth century, the East India Company had established local recruitment to fill the ranks of its armies in the three presidencies. At the turn of the twentieth century, the Royal West Africa Frontier Force and the King's African Rifles helped to garrison and police Britain's African possessions. World War I underlined the dependence of the empire on the Indian Army and other non-white units and was clearly an imperial, rather than simply a British effort. For example, over 550,000 members of the Indian Army served overseas, the campaigns in Africa drew on the service of over 1 million carriers during the course of the war and territories as far flung as Fiji and the Bahamas provided contingents. $^{2}$

The British Army remains a multiethnic force today, despite British-born minority ethnic groups being underrepresented in the ranks. In 2002, one in six combatant troops was not born in Britain, many hailing from the Commonwealth. ${ }^{3}$ In 2006 3,000 Nepalese, 2,000 Fijians, 975 Jamaicans, 720 South Africans, 565 Zimbabweans, 280 Vincentians and 225 St Lucians were enlisted. Data from the Ministry of Defence suggest the reliance on overseas recruits is likely to continue, particularly in the context of the UK's commitments in Iraq and Afghanistan. ${ }^{4}$ However, the sacrifices of non-white troops who have helped to sustain British military campaigns, both past and present, often goes unrecognised. The collection of films in the Imperial War Museum (IWM) that records the contribution of imperial troops is an invaluable, if currently underused, resource in helping to redress this historical omission. These film texts also offer researchers insight into the complexities of military service within an imperial context. During World War I, as the examples below demonstrate, imperial categories of race and masculinity were being increasingly called into question. Film-makers reflected the ambiguities of this 
moment as they attempted to project conventional racial hierarchies, while presenting the vision of a united empire and acknowledging the martial capacities of non-white troops.

Interest in the wartime experiences and contribution of black and Asian troops has increased steadily over the past four decades, inspired by 'history from below', subaltern studies and 'the new imperial history'. Several other significant influences in the burgeoning of this field of research may be observed, including the assertion of new national identities in the post-imperial era; the imagining of an imperial heyday of paternalism and cooperation; and the affirmation of citizenship by diasporic communities in Great Britain through the ancestral sacrifice of imperial subjects in the World Wars. The rehabilitation and reworking of war memory is not therefore limited to a narrow association with a single nation-state. Jamaican subjects, for example, ostensibly volunteered to defend the British empire, but subsequently within the popular imagination also served the cause of pan-Africanism, the independent Jamaican nation and its diaspora. The rediscovered participation of black and Asian troops in the World Wars can play a significant part in asserting contemporary claims to citizenship and social inclusion. But the recovery of such historical memories is not unproblematic. Discourses of national belonging and citizenship may come to depend on a post-imperial nostalgia that privileges military service, especially front-line duty and the imagining of heroic hand-to-hand combat. ${ }^{5}$

Archive film footage can play an important part in the recovery of war memory and, where footage is relatively scarce, film fragments can in themselves become emblematic or objects of antiquarian curiosity. It is important therefore to retain a sense of historical context and to measure film evidence against existing documentary sources. This paper therefore discusses the provenance of the collection and the institutional, historical and practical issues that have contributed to the neglect of this field by curators, historians, teachers and television researchers. It then provides an overview and contextualisation of some of the key items of World War I film relating to non-white forces held by the Imperial War Museum to assess the importance these may play in the historical memory.

\section{PROVENANCE AND SCOPE OF THE IWM COLLECTION}

There are 1,235 films listed in the museum's catalogue for the World War I period. The majority were acquired between 1919 and 1921 when the museum became the custodian of all 'official war films' commissioned by the War Office, Admiralty, Air Ministry and Tanks Corps and which recorded British and imperial military forces in all theatres of armed conflict. The museum also received government-funded information and propaganda films about and for the home front, a near complete series of the wartime newsreel Topical Budget (taken over by the War Office in 1917) and eighty-two issues of Annales de la guerre (from May 1917 to December 1918), acquired from the French Government. During the interwar period this core collection was supplemented with material from the commercial newsreel companies, including 'documentary' histories of the war, such as The World's Greatest Story (1919) and Our Empire's Fight for Freedom (1918) and official films produced by other combatant 
powers - Germany, Russia and the US. The museum also made agreements to exchange films with Australia, Canada and New Zealand.

India and members of the Indian forces are referred to in over eighty films produced during the World War I era. Sixteen of these were shot on the Western Front (France and Belgium), twenty-six cover Indian forces in Palestine and seventeen in Mesopotamia. Indian troops also appear in one film shot in Egypt, three filmed in London, one in Paris and a couple in the Balkans. Black Africans serving in World War I are covered in nine titles ${ }^{6}$ with men of the British West Indies Regiment (BWIR) appearing in a further three (West Indian agricultural workers also feature in a section on sugar production in Trinidad in the British official film Feeding a Nation of 1918). ${ }^{7}$ The appearance of West Indians in two additional films is to be confirmed. ${ }^{8}$ Researchers working in this field may be familiar with South African Native Labour Contingent: Somewhere in France (November 1917), discussed in more detail below, but will not know of an Egyptian Labour Contingent (December 1917), which follows this unit from its recruitment and training in Egypt to its arrival in France, and bears similarities in its treatment of native uniformed labourers with that of the South Africans in the earlier film. ${ }^{9}$

Researchers are also directed to Chinese Labour Contingent (November 1917), held at the IWM in a Spanish version, and which is one of ten films covering this unit in France ${ }^{10}$ Four films in the collection include scenes of Māori soldiers; the first shows a group recuperating in England after seeing action at Gallipoli and the remainder Māori soldiers serving with the New Zealand Division on the Western Front. ${ }^{11}$ There is also film of Edward Prince of Wales meeting Maori veterans at Rotorua, during his world tour in $1920 .^{12}$ There are eight films of the Arab horsemen and soldiers who were supported by the British and French in their uprising against the Turks in Arabia. ${ }^{13} \mathrm{~A}$ number of films show locally recruited native peoples, working for the British military forces as non-uniformed labourers in various overseas war zones (e.g. women refugees in Mesopotamia). ${ }^{14}$ Non-white troops are also found in films produced by the French and Americans. For example, native troops from French African colonial possessions (Algerians, Annamites, Moroccans, Senegalese and Spahis) are found in ten films, all but one being from the Annales de la guerre newsreel series produced by the Section Cinématographique de l'Armée Française. African American soldiers appear in seven films, four produced by the US Signal Corps, two British official titles and one issue of Annales de la guerre. ${ }^{15}$ An African prisoner of war (POW) in a German-run camp in Belgium even appears in an issue of the German wartime newsreel Messter Woche (1915). ${ }^{16}$

Compared with the overall size of the IWM's World War I holdings, the number of films featuring non-white colonial forces is small. However, one should not assume this was due to deliberate or unconscious attempts to disregard the contribution made by colonial forces to the Allied war effort. As discussed below, British propagandists made much of the colonial contribution. The support of potentially millions of soldiers from the empire was a valuable way of boosting civilian morale in a beleaguered and isolated Britain. This is well exemplified in Lancelot Speed's animated cartoon, Britain's Effort (1918), in which John Bull is joined by nations of the empire represented by animal mascots - Canada (moose), Australia (kangaroo) and India (elephant). Furthermore, and again exemplified by this cartoon, the British cause was morally 
strengthened when it could be demonstrated that men from scattered, remote colonies and Dominions were willing to volunteer to fight for the mother country.

One of the main reasons for the relative lack of coverage of colonial troops is that for most of the war they were not serving in the theatres of conflict where official filming was best organised - the Western Front. Even here the first two cameramen did not arrive in France until the beginning of November 1915 and there were never more than three operating at any one time. Elsewhere, film coverage was patchy. There was one official cameraman on the Salonika Front for about a month in the spring of 1917, a cameraman in Mesopotamia from July 1917 to June 1918, a cameraman in Egypt and Palestine with the Egyptian Expeditionary Force from May 1917 to October 1918, and a cameraman in Italy from December 1917 to January 1918 and again in June 1918. By the end of 1915, most of the Indian Corps apart from two Divisions of the Indian Cavalry Corps had been withdrawn from the Western Front to serve in Mesopotamia, Egypt, Palestine and the Balkans. African troops mainly fought in Africa itself and, although battalions of the BWIR did serve on the Western Front, they were routinely switched to depots in Palestine, Egypt and Italy during the winter months.

On reflection, given the small number of colonial troops on the Western Front after the beginning of 1916 and the poor film coverage of British military forces in other theatres, colonial troops are perhaps reasonably well represented in the film record. This is not to argue that the treatment of colonial forces in these films is on a par with the representation of white British and imperial troops. As discussed below, the portrayal of colonial forces is often problematic, in many cases reflecting the racialised perceptions that ranked colonial peoples according to ascribed martial characteristics.

\section{SHOOTING AND PRODUCTION OF OFFICIAL FILMS}

Until July 1915 filming was forbidden on the Western Front, but gradually cameramen were given access. In November 1915, two cine cameramen, William Tong and Geoffrey Malins were appointed to cover the British Army and its Allies on the Western Front. Filming was overseen by a War Office committee of leading commercial newsreel and documentary companies. The committee was given the right to film on the Western Front in exchange for agreeing to share film rental profits with War Office charities. The cameramen sent to film in France were commercial newsreel cameramen. William Tong had been a cameraman with Jury's Imperial Pictures, Geoffrey Malins was working for Gaumont Graphic at the start of the war and J. B. McDowell had been employed by the British and Colonial Kinematograph Company. F. W. Engleholm, appointed by the Admiralty to cover the Royal Navy's wartime exploits, had been working with Topical Budget.

Once appointed, the War Office ensured that these cameramen were controlled by and fully inculcated into the ethos of the British Army. They were issued with officers' uniforms, billeted and fed at general headquarters (GHQ), and salaried at $£ 1$ per day. The cameramen were transported by military vehicle and assisted by a soldier who helped carry their equipment. They were always escorted by a conducting officer, most 
usually Captain Faunthorpe, the military director of kinematographic operations, who told them where and what they could film.

The exposed films were returned to England for processing, editing and titling, the latter task being controlled and undertaken by the War Office, which in practice meant that the titles were written by Captain Faunthorpe. A rough cut of the film was then passed to the War Office for approval, with this version then being sent to GHQ in France for further censorship, before being finally returned to England for printing and distribution to the cinema trade.

Although the British obtained film from all war zones, beyond the Western Front the War Office often relied on independent commercial cinematographers to provide coverage or supplement the output of individual official cameraman. Footage of British forces in Mesopotamia was obtained by a deal with the American Ariel Vargas of International Film Services. Another American, Lowell Thomas, supplied footage of Palestine, notably of the Arabian forces partly established through the efforts of T. E. Lawrence. There were no official cameramen in East Africa or Gallipoli and the only coverage of these campaigns was supplied by the unofficial amateur cameramen Cherry Kearton (Operations of the British Expeditionary Forces in East Africa, 1916) and Ellis Ashmead Bartlett (Heroes of Gallipoli, 1920).

\section{INSTITUTIONAL AND PRACTICAL ISSUES CONTRIBUTING TO THE NEGLECT OF FILM OF IMPERIAL TROOPS}

Despite the importance and richness of the IWM collection, it has been neglected by historians of race and empire. With the exception of a couple of episodes from the 1964 BBC Great War series, archive film covering Britain's imperial forces was rarely seen until the late 1990s. Between 1970 and 2010, the IWM's Film and Video Archive supplied footage to three television productions about non-white troops during World War I - Mutiny (1999), about the BWIR and Unknown Soldiers (2000), about the contribution of African, Asian and West Indian British empire servicemen to World Wars I and II, and Black Flash (2006), about colonial troops in the trenches. By contrast for the Battle of the Somme, there are fifty-nine production files for programmes on this topic. Until recently, there was also little scholarly research into the films covering non-white members of the British armed forces, and few people visited the museum to view these films. ${ }^{17}$

This neglect may be attributed to a number of factors. Despite being the world's first film archive, this is still a collection that is not widely known beyond specialist military historians. Much of the footage, particularly from the World War I era, consists of films presented in a form far removed from the modern concept of the moving image - black and white, mute and unedited. Finding footage covering non-white imperial troops can be difficult due to the range of nomenclature for non-white people in the catalogues, including pejorative or idiomatic terms such as 'native', 'colonial', 'coloured' or 'negro' where these words have been used in the original film intertitles. Military units and individuals have not been identified on the basis of ethnicity, unless ethnicity was specifically referred to in the actual name of a unit, such as the South African Native Labour Corps (SANLC) or the British West Indies Regiment. 
Moreover, cataloguers have tended not to identify a non-white soldier among a unit of white troops. For example, in Topical Budget 272-2 (11 November 1916), an item titled 'The Armies of the Allies. An Interesting Group of Nationalities Fighting the Central Powers in the Balkans. British, French, Russian, Italian, Serbian, Indian, Cretan, Senegalese, Greek and Annamite Type of Soldier', featured a range of ethnicities, including two black Africans from Senegal and an Indian Sikh. The last item in the same issue of Topical Budget presents a more striking example of this problem. It records the visit of the King of Belgium's military band to the UK and, among the group of uniformed Belgians, is a black soldier, presumably a man originating from the Belgian Congo. However, the cataloguer did not mention this individual, even though he was one of two men inspected by Viscount French.

Apart from these practical factors that have hindered access to the collection, there is also the historical neglect of this whole topic by British society, reflected in the lack of scholarly interest in this part of the IWM collection and the few films and television programmes made on the subject. British society's comparative indifference to the history of Britain's non-white colonial allies and comrades has also been reflected in the IWM's exhibitions and public programmes. The current permanent gallery narrating World War I, opened in 1989, gives little coverage to the involvement of non-white troops. Indian troops, whose numerical contribution to the empire forces was second only to Britain's, receive scant attention. There is reference to Indian troops in the Mesopotamian campaign, but no account of their crucial role on the Western Front in 1914/15 or the Indian Brigade in Gallipoli; two divisions who fought in Palestine are only covered in the interactive video. There were also few attempts to promote parts of the collection recording this history through loans and educational work. It was not until 1990 that the museum's film and video loan scheme for higher education included titles covering non-white colonial forces. Only from September 2003 did such films feature in the daily cinema screening programme for school parties. $^{18}$

Some IWM historians and curators felt that the contribution made by non-white colonial forces was (perhaps with the exception of the Indian forces) marginal to the military histories of both World Wars. There was also an argument, born out of the spirit of both World Wars, but especially World War II, that to identify members of the armed forces on the basis of their ethnicity and relate the history of the wars on this basis undermined the spirit of common endeavour that had united the peoples of the British empire against a fundamentally racist and undemocratic regime. Another institutional factor that contributed to this marginalising of the history of non-white troops, and therefore the films that recorded it, may be explained by the fact that white people did and still do dominate the curatorial staff of the IWM, as is the case in most museums and cultural institutions in the UK. Since the late 1990s, there has been an active effort on the part of the museum to reverse this attitude, and since 2005, this new thinking has been enshrined in the institution's policy:

To review collections, research, exhibitions, public and learning programmes and budgets on a continuing basis with the aim of achieving greater diversity in their use. To also ensure that exhibitions and public learning programmes with a diversity facet are funded and embedded over the long term rather than relying on project funding. ${ }^{19}$ 
Long before this change in IWM policy, and the recent efforts of the Arts and Humanities Research Council 'Colonial Film' project to document the non-white histories in the collections, attitudes were changing behind the scenes. A new generation of historians joined the museum, who reflected a more progressive attitude to race in British society. In the 1980s cataloguers, recruited primarily for their historical expertise rather than as librarians or for their knowledge of film theory, began to systematically catalogue the film collection. An informal policy seems to have been adopted, which started to identify non-white people in the catalogue notes who had not been mentioned in the original titles. This is particularly noticeable in the catalogue for the World War I collection. On a number of occasions film cataloguers diligently recorded the appearance of black or Asian subjects. For example, in 1983 the cataloguer Stephen Badsey pointed out in the notes to War Office Topical Budget 353-1 (IWM 675b, 27 May 1918), which recorded a visit by Lloyd George to Edinburgh, that two Africans or West Indians (possibly students) appeared in the crowd greeting the prime minister. Similarly, in another issue of the War Office Topical Budget 367-1 (2 September 1918), which recorded the king decorating servicemen at Buckingham Palace, Badsey mentioned that Indian troops were among those receiving medals. ${ }^{20}$ Ironically, this effort to identify non-white troops reflects an awareness of the IWM's historical obligations to the legacy of the British empire that derive in part from its name, a title that many now feel is anachronistic.

\section{THEWESTERN FRONT}

\section{The Indian Division}

We now turn to a discussion of some of the most significant pieces of footage in the IWM collection. The importance of colonial troops to the British cause may be indicated by the fact that the first official film of the Western Front released to British audiences was With the Indian Troops at the Front (January 1916). ${ }^{21}$ From the beginning of the war, Indian troops featured regularly in commercial newsreels of the war, receiving coverage in at least seven issues released in Britain prior to the release of With the Indian Troops. Footage included the Indian Corps arriving at Marseilles in September 1914; Indian troops at Arras in the winter of 1914/15, returning 'for rest after weeks of hard fighting'; and an item subtitled, 'Our Gallant Indians Cured of Their Wounds Returning to the Front', which recorded troops from various units (Sikhs, Gurkhas, etc.) marching along a rural English road, lined with waving civilians before entraining at a station. ${ }^{22}$ A Canadian, Hilton de Witt Girdwood, was appointed official photographer to the Indian Army. He filmed Indian troops in a semi-official manner during the Flanders fighting of July 1915, although his film, With the Empire's Fighters (September 1916), has not survived.

With the Indian Troops, which portrays the Indian Division on the Western Front in late 1915, may have underlined the increasing remoteness of the war to metropolitan audiences, perhaps highlighting the gulf between civilian and military experiences identified by Paul Fussell in many literary responses to the war. ${ }^{23}$ However, the validity of such a divide has subsequently been called into question by critics of Fussell, who 
highlight the impact of total war, particularly in terms of the changes in gender identity, and the privileging of white male literary voices. It is equally important to recognise that, while the Indian population in Britain during this period could perhaps only be numbered in the hundreds, India occupied a central place in the British imagination, not only in terms of the colonial products that had become everyday items in British life but also the images of Indian military traditions and spectacles. In the two decades before World War I, colonial and imperial troops had marched through London on several occasions. As well as Queen Victoria's Diamond Jubilee, non-white troops were also present at the coronations of Edward VII in 1902 and George V in June 1911. All three events were filmed and screened to public audiences. ${ }^{24}$

In February 1912, Charles Urban's lavish two-and-a-half-hour Kinemacolor film of the Delhi durbar - the coronation of George V as emperor of India - was shown at the Scala Theatre in Charlotte Street. The commercial success of the production highlighted the central role of royalty, empire and military spectacle in the development of a mass audience for cinema. ${ }^{25}$ From December 1914 to January 1916, the Indian presence in Britain became increasingly visible when the Brighton Pavilion was converted to a military hospital for Indian soldiers wounded on the Western Front. Partly as a propaganda exercise to present the benevolent face of empire, thousands of postcard images were circulated showing the newly converted facilities, which included prayer rooms and other facilities to cater for the needs of Muslim, Sikh and Hindu soldiers. ${ }^{26}$

Rather than signalling the war as an alien and remote experience, With the Indian Troops continued this tradition of signalling the war as a common imperial effort, linking the British home front with colonial possessions and the troops serving on the Western Front. This issue became particularly important once war had been declared on Turkey in November 1914 and both the military and the India Office became increasingly concerned to preserve the loyalty of the subcontinent's Muslim population. ${ }^{27}$ Racialised difference is to a limited extent elided. The Indian soldier becomes domestic and familiar, a long cry from the potentially mutinous and murderous sepoy of 1857. This is underlined in the sequences of Indian soldiers engaged in everyday tasks, then commonplace in both civilian and military life digging, carpentry, cutting timber, caring for horses. Here is the image of an empire united in adversity, an 'Empire in arms against German tyranny' in the words of a military padre working with West Indian troops. These concerns and representations of a less hierarchical empire were underlined when, with voluntary enlistment drying up, King George V issued his 'Appeal for Men', which was distributed throughout the empire in October 1915 as the sequences of With the Indian Troops were being filmed:

At this moment in the struggle between my people and a highly organised enemy ... I appeal to you.

I rejoice in my empire's efforts, and feel pride in the voluntary response from my Subjects all over the world who have sacrificed home, fortune and life itself, in order that another many not inherit the free Empire which their ancestors and mine have built.

I ask you to make good these Sacrifices ... I ask you, men of all classes, to come forward voluntarily and take your share in the fight.

In freely responding to my appeal, you will be giving your support to our brothers who, for long months, have nobly upheld Britain's past traditions, and the glory of her Arms. ${ }^{28}$ 


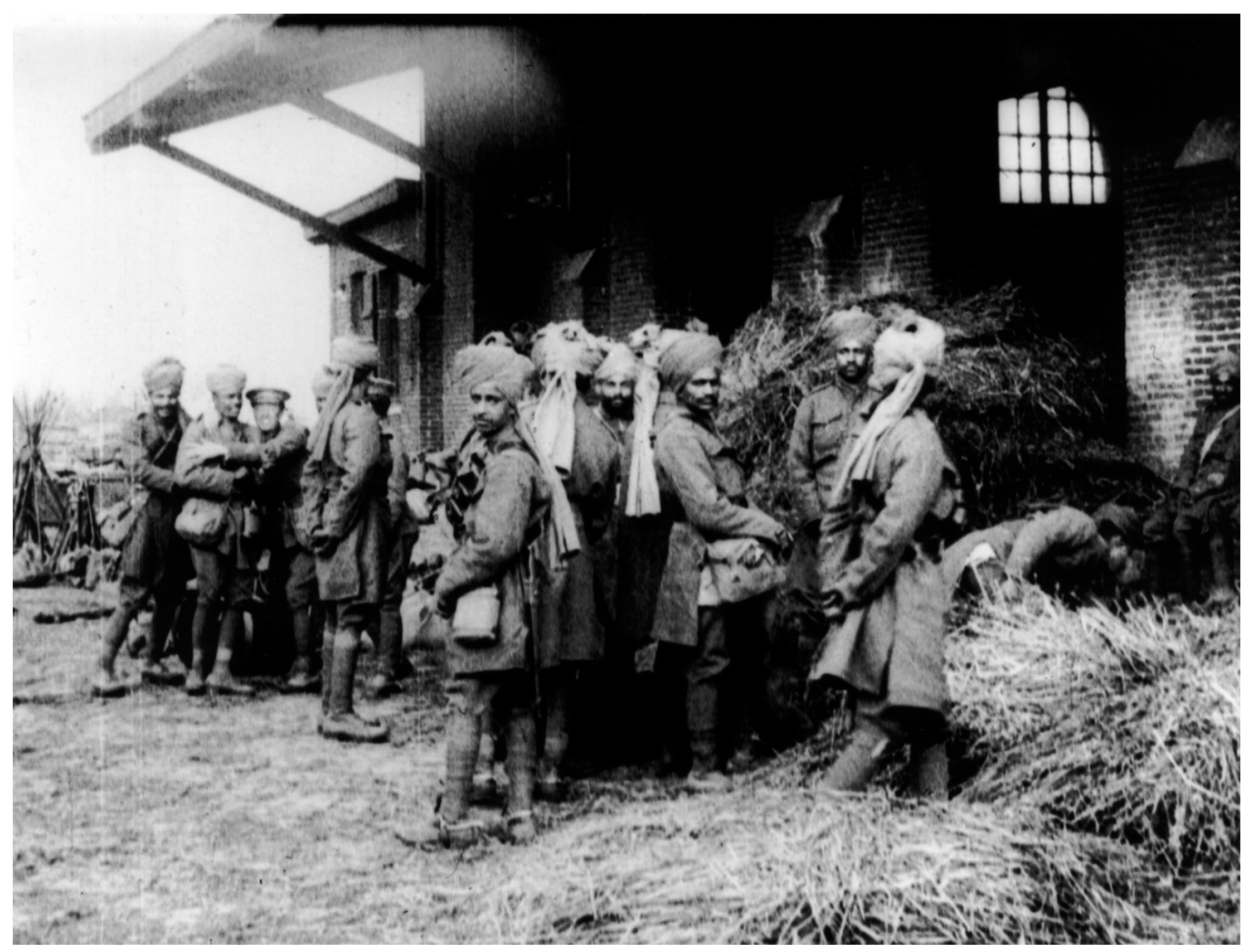

With the Indian Troops at the Front (1916). Courtesy of the Imperial War Museum (IWM FLM 42। I)

The focus on imperial subjects can result in the white British soldiers taking almost a subsidiary or auxiliary role. This is underlined when, in a brief sequence Indian soldiers light-heartedly jostle white soldiers who are endeavouring to enter the frame. Alongside the Indian troops in domestic and familiar poses, there is also a reminder of Indian military prowess. We see the rituals associated with military tradition - Sikhs offering the blades of bayonets for the officer to touch, Gurkhas sharpening their traditional kukri swords. The juxtaposing of Sikh and Muslim troops with Scottish Seaforth Highlanders suggests an attempt to present a popular version of martial race theory to a mass audience. Martial race taxonomies were developed by the British and Indian Armies in an attempt to demarcate the recruiting grounds in South Asia, Africa and the Celtic periphery. ${ }^{29}$ Martial race theories were increasingly significant in the wake of the Indian Mutiny of 1857. Up until this point, the British had recruited with little discrimination and much pragmatism in order to sustain military campaigns and policing operations. But in the wake of 1857 , non-whites were increasingly caricatured as unreliable and potentially traitorous, as well as falling short of British ideals of heroism, military élan and steadfastness. The black presence in the army as a whole 
declined and racial theories were elaborated that attempted to dictate the racial groups from which colonial armies could be recruited. ${ }^{30}$ Closely aligned with scientific racism, martial race theories held that some races possessed predetermined fighting qualities, which were in turn influenced by cultural practices and climate. After 1857, the main recruitment grounds for the Indian Army were redefined, the northern states replacing the south and east. Tropical climates were believed to dissipate manliness and so hilldwellers from cooler climes, such as Nepal, were preferred over the plainsman of southern India. The so-called Aryan races of north India were also regarded as superior as it was believed they shared a common Euro-Indian heritage. Often however, martial theories were pragmatically adapted to meet recruiting targets. ${ }^{31}$

Recruitment policy in imperial Africa from the 1880s was also informed by martial race thinking. Men from remote, impoverished regions were preferred as they were held to be able to survive on irregular food supplies and to have natural scouting skills. Groups who had previously resisted colonial rule, such as the Nandi of Kenya, were also favoured. ${ }^{32}$ But, in all cases, it was believed that martial capability could only be fully realised under white leadership.

Whatever concessions to non-white races were encompassed within martial race theory, white predominance could never be brought into question. As the nineteenth century progressed, the model of white military masculinity upholding ideals of selfcontrol and rationality became more entrenched. Wherever non-white units were raised in the empire, they were led by white officers. Non-whites were only able to rise to the rank of non-commissioned officer (NCO) in the 'native regiments' as they came to be designated. ${ }^{33}$ The one exception was the Indian Army, where Indian officers could receive commissions from the viceroy. Their main purpose was to advise white officers, particularly on cultural matters. However, Indian officers remained subordinate to their white counterparts regardless of rank, as the latter held the king's commission. Furthermore, the proportion of Indian officers in relation to whites declined as the war approached. By 1914, each unit contained matching numbers of white and Indian officers, reflecting the feeling of the military establishment that units officered solely by Indians would not act decisively in the front line. ${ }^{34}$

So while simultaneously presenting the image of a united empire, there is also a suggestion in these films that racialised difference and hierarchy must be preserved. So while images of Indian troops, for example, may have a familiar immediacy, the films retain a sense of otherness. In this respect they represented recognisable 'types' in a way that was also visible in educational texts, children's storybooks and anthropological studies during this period, which frequently identified peoples by rituals or customs, whether these be Indian soldiers engaged in traditional wrestling or Scottish Highlanders breaking into impromptu reels. ${ }^{35}$

When we watch With the Indian Troops, it is important to consider the impact that the presence of Indian troops in Europe had elsewhere in the empire. Many men in the West Indies, for example, were inspired to volunteer when they saw pictures and reports about the Indian contribution on the Western Front in West Indian newspapers. ${ }^{36}$ Although after two winters in France, the morale of the Indian soldiers was beginning to falter, partly due to high casualty rates among officers, but also because Indian customs of military service were not recognised. 


\section{The British West Indies Regiment}

The Battle of the Ancre marked the final stage of the Somme campaign in autumn 1916. In terms of commercial and popular success, The Battle of the Ancre and the Advance of the Tanks (1917) was second only to the Battle of the Somme (1916). ${ }^{37}$ The film contains in a brief ten-second fragment one of the very few moving images of troops from the BWIR, who are seen rolling shells towards light railway wagons near the front line. The fleeting glimpse of the BWIR has escaped the notice of the intertitle writer, despite the slightly clumsy editing at this point. Formed in November 1915 for the duration of the war only, the BWIR comprised twelve battalions and recruited over 16,000 men from the West Indies, British Honduras, the Bahamas and Bermuda. Like many other non-white units in the European theatres of war, the BWIR was restricted to labour battalion duties, even though the regiment had been established as an infantry unit. The Army Council, the army's supreme authority, declared that 'coolness, courage and initiative are at a premium [in the front line] - qualities of which the ordinary coloured labourer is deficient'. But these attitudes contrasted with those white men who had seen the West Indian soldier in action. Alfred Burdon Ellis, officer and historian of the West India Regiment, believed black West Indian troops were superior to whites in harsh tropical conditions. He claimed black troops could march two to three times the distance of white comrades and could match European troops even when on half rations. According to Ellis, 'the principal difficulty with [the West Indian soldier] in action is to hold him back, so anxious is he to close with his enemy. ${ }^{38}$

In reality, as this brief scene shows, the division between front-line and support troops was a semantic one and the BWIR suffered many casualties during artillery attacks. Given the pressing need for personnel, prejudice alone does not explain the British reluctance to deploy black soldiers on front-line action in Europe. Rather, there was an underlying fear that black soldiers might outperform their white counterparts, with deep implications for the hierarchy of empire. Ideas of white masculine prowess, characterised by heroic endeavour, stoicism and self-control, had been brought into question by the epidemic of psychiatric disorders afflicting the British Army. ${ }^{39}$ Ideals of white masculinity were also undermined by the poor physique of many recruits who were assigned to the labour battalions or home garrison duty. ${ }^{40}$

To preserve imperial racial hierarchies on the Western Front, West Indian soldiers were routinely excluded from social facilities, such as camp cinemas and estaminets (soldiers' cafés). Men requiring medical services were regularly treated in the 'native' hospitals reserved for South African, Chinese, Egyptian and Indian labour contingents, where treatment and accommodation fell below the standard applied to German prisoners of war. Deaths from disease were disproportionately high as a result. The BWIR was also excluded from the pay increases awarded to other regiments and it was not until mid-1919, after vigorous protest, that the matter was finally redressed. This discrimination in pay and conditions, and a sense among many volunteers that they had been denied an equal place in the firing line, culminated in a mutiny of BWIR battalions stationed at the port of Taranto, a key logistical base in Italy. $^{41}$ 


\section{The South African Native Labour Contingent}

Between November 1916 and January 1918, 25,000 black South Africans were recruited to serve as labour battalions in France, as supplies of European labour dried up. A further 35,000 black South Africans supported the campaigns in German West Africa (Namibia). Like the West Indian troops on the Western Front, black South Africans, despite their longstanding military service, were not deployed as front-line troops. There were particularly strong concerns in South Africa that white supremacy would be called into question should black soldiers defeat a white opponent and there were protests in the dominion when Indian troops were deployed on the Western Front. Even the use of black South Africans in labour battalions was viewed as problematic in case the local labour supply was disrupted, especially as members of the SANLC were paid 10 per cent more than the average South African wage. Many black South Africans were also reluctant to volunteer as they feared their lands might be confiscated in their absence under the Native Land Act introduced the year before the war. The military and colonial authorities were also keen to ensure the segregationist policies maintained in South Africa would be enforced in France. The SANLC was therefore deployed on forestry and quarrying work, which would ensure a degree of separation from white civilians. Segregation was underpinned by the cantonment of the SANLC in camps.

The SANLC was filmed in November 1917 by the Topical Film Company. ${ }^{42}$ Like the footage of the Indian Division in France, these images of South Africans engaged in everyday tasks - tree-felling, road digging and uploading supplies - rather than military manoeuvres, convey a certain domestic familiarity. At the same time a racialised division of labour is clearly upheld. White soldiers carry out technical tasks such as operating mechanical saws, while black soldiers carry out the manual labour. In early 1917, War Office officials suggested that the replacement of white Royal Engineers "by coloured men would ... be most dangerous to the efficiency ... of the armies in France. ${ }^{43}$ The scenes of South Africans digging roads and breaking stones are particularly telling with the association of colonial penal labour and public works schemes for the rural unemployed.

Despite allusions to their status among fellow black South Africans, 'native chief' NCOs are presented as inferior to the white officers in the footage. Indeed, 'native' was a designation routinely used by the War Office to pay black units, such as the West India Regiment and the BWIR at a lower rate of pay, even though they were line regiments of the British Army. The Indian Army had made longstanding use of indigenous officers to act as intermediaries, but Indian officers holding a viceroy's commission could never wield authority over a white Indian Army officer holding the king's commission. ${ }^{44}$ There is clear anticipation here of the indirect rule policies advocated by Lord Lugard in the 1920s in which imperial authority was retained behind the smokescreen of local authority figures. ${ }^{45}$

An early sequence in this newsreel appears to show members of the BWIR unloading supplies from railway wagons. The West Indian troops can be identified by the wearing of regular-issue uniforms and caps with badges. Under General Routine Orders, SANLC soldiers were issued with the navy corduroy trousers and jackets, blue greatcoats and Gurkha-pattern hats, evident in the remainder of the film. A clearer 


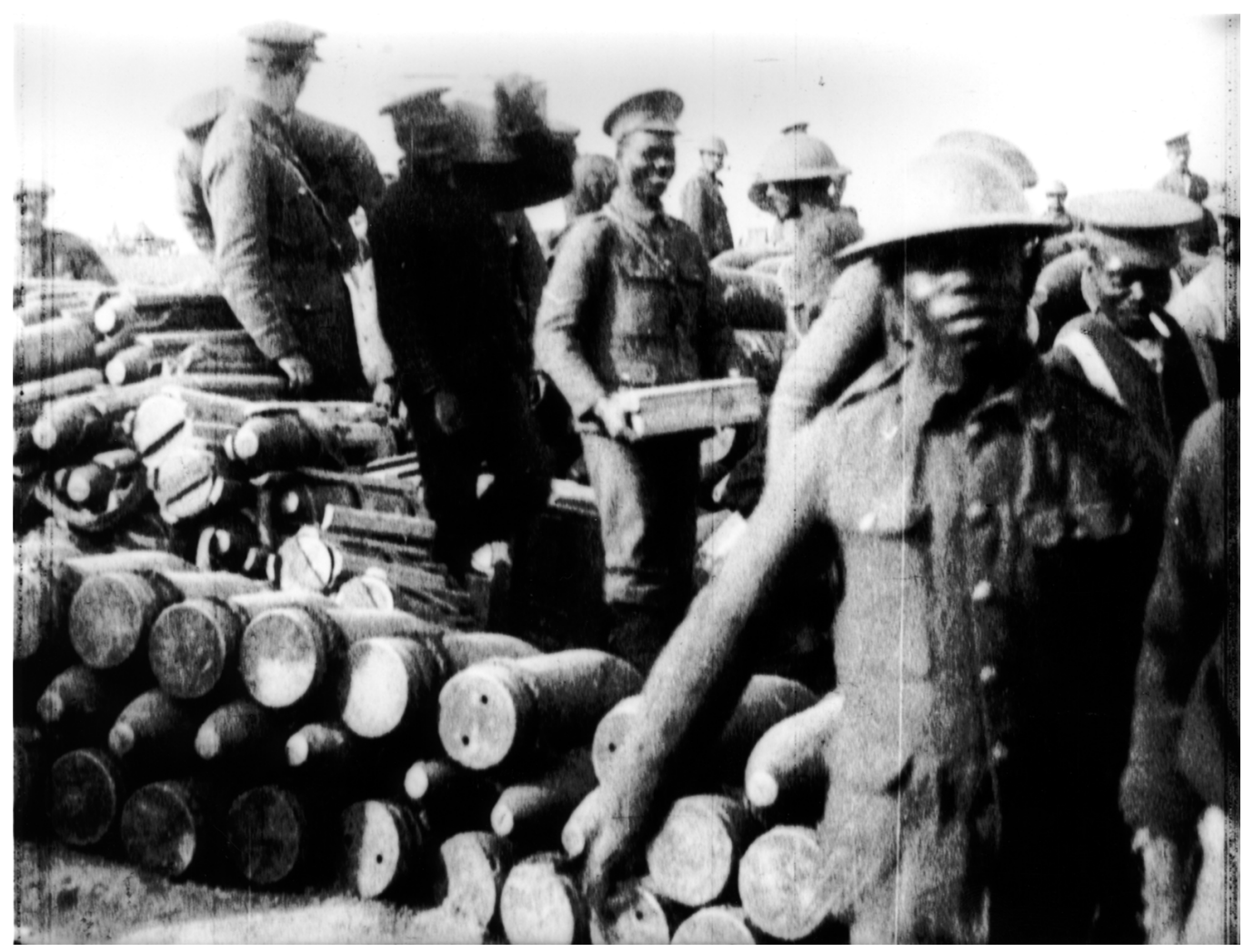

Sons of Our Empire (1917). Courtesy of the Imperial War Museum (IWM FLM 4213)

mis-cataloguing of the BWIR occurs in Sons of Our Empire (Episode 3). ${ }^{46}$ Here the intertitle erroneously identifies a group of West Indians unloading shells as 'West Africans of the Labour Corps'. No West African troops or labourers were deployed by the British Army on the Western Front. Such misidentification raises a number of issues. Film-makers did not automatically engage with preoccupations with racial-type evidence in much imperial thinking. Where it served a narrative purpose, taxonomies of race were much in evidence. In more pragmatic terms, a shortage of stock footage or editorial effect could lead to the blurring of racialised categories as evident in South African Native Labour Contingent Somewhere in France.

\section{The Māori Pioneer Battalions}

The first Māori contingents were raised in early 1915 and fought at Gallipoli. After Gallipoli, they were reformed as the Māori Pioneer Battalions comprising around 2,200 Māori and 500 Pacific islanders after campaigns by Peter Buck (Te Rangi Hiroa) a 
politician, doctor and anthropologist of Māori heritage. It is hard to understand why the Māori battalions were regrouped as labour battalions, given their strong martial tradition. It seems most likely that this was a way of ensuring they did not step outside their place in the imperial racial hierarchy. Many Māori did enlist in the other New Zealand infantry regiments. ${ }^{47}$

Despite the Mãori contribution, the Anzac legend of 'mateship' and the stoical 'digger' centred on the Gallipoli campaign has tended to be a largely white affair. ${ }^{48}$ The Mãori Pioneer Battalions were stationed in France from April 1916 until the end of the war. They were filmed during a visit by New Zealand premier William Massey and his deputy Sir Joseph Ward to the Western Front in 1918. ${ }^{49}$ Massey and Ward are seen reviewing the Māori troops in a characteristically jovial and informal fashion. In one section cigars are shared with the troops. More significantly, the film captures how, despite the whiteness of the Anzac myth and the exclusion of Mãori troops from the front line, elements of Mãori culture have become incorporated into New Zealand national identity. The most notable example is perhaps the haka, which the Mãori troops demonstrate in this footage. In frontier societies, such as New Zealand, racial identities had the potential to become blurred, particularly where white settlers perceived martial qualities that could be admired in, or even appropriated from, local peoples. Such qualities perceived in a subject race, and which were usually regarded as innate, rather than acquired and complex, could be deployed to underpin a vigorous settler identity, which was often cast in opposition to purported metropolitan enfeeblement and enervation. ${ }^{50}$

\section{BEYOND THEWESTERN FRONT}

The campaigns in both East and West Africa are often overlooked. In these campaigns both the Allies and the Germans were heavily reliant on locally recruited troops. There was also a marked dependence on locally recruited carriers and other auxiliary labour to maintain the troops in the field, which were notable for improvised and guerrilla war tactics. ${ }^{51}$ To both the British and the Germans, the advantage of using local troops and labour reduced the dependency on lengthy and resource-heavy supply routes. But the semi-enforced enlistment of black soldiers and labourers and the heavy depletion of local resources for the war effort had disastrous long-term consequences for local African economies. ${ }^{52}$

The role of African troops and labourers is captured in film shot by the naturalist and wildlife film-maker Cherry Kearton in Operations of the British Expeditionary Forces in East Africa: Our Grip on the Huns (1916). ${ }^{53}$ Men of the King's African Rifles, formed in 1902 and recruited in Nyasaland, Kenya, Uganda and Somalia are seen on patrol and the reliance on local canoes to maintain supply routes is highlighted. ${ }^{54}$ Kearton was serving in East Africa with the 25th Royal Fusiliers (Legion of Frontiersmen), a battalion raised by the Boer War veteran Colonel Daniel Patrick Driscoll. The Frontiersmen battalion was an eccentric group of big-game hunters, explorers, showmen and artists, lured by the promise of adventure and the chance to test their masculinity on the margins of empire. Kearton's freelance footage, which was also shown alongside official films, captures the spirit of the battalion, which prided itself 
on improvisation and backwoodsmanship. The footage includes the casting of a primitive trench mortar in the field and the construction of bivouacs and improvised field kitchens. Kearton's first preoccupation is with the landscape and environment. The opening sequence is captioned 'Midst the Wild Beasts ... A Glimpse of the German East African Country', which reflects a preoccupation with the picturesque, but nevertheless menacing landscape, rather than the human presence. Kearton's published account of his wartime service is similarly interspersed with such interludes, including a menacing encounter with lions at a watering hole. ${ }^{55}$ The usual hardware associated with the industrialised slaughter of the Western Front is little in evidence, apart from brief footage of a reconnaissance plane and a heavy field gun that appears be deployed to subdue the landscape, as much as defeating the German forces. Any heavy equipment was carried over long distances by African carriers, many of whom found themselves forcibly enlisted by both sides. ${ }^{56}$ Kearton himself was carried by two porters after being injured. ${ }^{57}$

A fleeting sequence of the British West Indies Regiment on the march during the Middle East campaigns can be seen in footage shot by the Topical Film Company at Deir El Belah, Gaza. ${ }^{58}$ Three battalions of the BWIR were engaged against the Turkish Army in Palestine and Jordan from the summer of 1917 to the end of the war. In July 1917, the machine-gun section of the first battalion took part in several raids on the Turkish trenches at Umbrella Hill on the Gaza-Beersheba line. ${ }^{59}$ Allenby, commanderin-chief of the Egyptian Expeditionary Force, was sufficiently impressed to state in a dispatch to the Jamaican governor,

I have great pleasure in informing you of the excellent conduct of the Machine Gun Section .... All ranks behaved with great gallantry under heavy rifle fire and shell fire, and contributed in no small measure to the success of the operations. ${ }^{60}$

\section{CONCLUSION}

This essay has highlighted the relative neglect of moving-image resources portraying the involvement of black and Asian imperial subjects in World War I. Although often fragmentary, these moving images of black and Asian soldiers and military labourers add texture and further insight to the other documentary sources in the field of new imperial history. These images, however fleeting, also provide a tangible link with the past for post-imperial nations and diasporic communities in the United Kingdom and yield powerful visual symbols to support the recovery of historic memory and claims to nationhood and citizenship.

Imperial attitudes to race and military service clearly impacted on cinematic representations of black and Asian troops. However, it is also clear that film-makers went to some lengths to emphasise the role played by imperial troops, recognising the importance a collective imperial effort had on national morale, the success of the imperial project and the legitimacy of the Allied cause. Wartime film-makers worked in strictly controlled environments and with limited access to imperial troops. This was especially so beyond the Western Front where the majority of black and Asian troops served. Nevertheless, effective use was made of the relatively small amount of footage 
taken. The subsequent neglect of this element of the IWM collection can be linked to a collective forgetting process within the British war memory that occurred with the realignment of British national identity during the era of colonial independence and mass migration from former imperial possessions.

Much of the IWM footage portrays black and Asian troops within the roles determined by imperial military ideology and the empire's division of labour: as martial races or domesticated, often emasculated labourers. However, the pragmatic considerations of both film-makers and military officials on the ground meant that some representations of imperial troops step outside these limited categories. Racialised identities are blurred and white martial supremacy is brought into question. These moving images of black and Asian troops assert claims for their wartime sacrifices and experiences to be recognised on equal terms with white imperial troops and to be fully integrated into the post-imperial war memory.

\section{NOTES}

1. Illustrated London News, 12 June 1897, p. 807.

2. Frederick William Perry, The Commonwealth Armies: Manpower and Organisation in Two World Wars (Manchester: Manchester University Press, 1988), p. 96; Geoffrey Hodges, Kariakor: The Carrier Corps: The Story of the Military Labour Forces in the Conquest of German East Africa, 1914 to 1918 (Nairobi: Nairobi University Press, 1999), pp. 34-5; 'British Island Colonies and the War', The Times History of the War vol. XVI (1918), pp. 73-108.

3. Sunday Mirror, 14 July 2002, p. 39; Observer, 21 July 2002, p. 6.

4. 'UK Army Has 10\% Foreign Personnel', BBC News Online, 13 September 2006, <news.bbc.co.uk/1/hi/uk/5342624.stm>; 'More Foreign Recruits Sign up for British Army', BBC News Online, 24 May 2010, <news.bbc.co.uk/1/hi/uk/8702135.stm>.

5. James Campbell, 'Combat Gnosticism: The Ideology of First World War Poetry Criticism', New Literary History vol. 30 (1999), pp. 203-15.

6. IWM 84, IWM 128, IWM 195, IWM 370, IWM 413, IWM 483-4, NTB 272-2, NTB 312-1, NTB 313-1.

7. IWM 10, IWM 116, IWM 130-5+6, IWM 548. The IWM holds the Spanish-language version of Feeding a Nation.

8. IWM 663a, IWM 675b.

9. IWM 413 and IWM 3. See also NTB 319-02 for scenes of the Egyptian Labour Corps on the harbour in France and IWM 77 for scenes of members of the Egyptian Labour Corps unloading supplies in Baghdad.

10. IWM 410, IWM 226m IWM 231, IWM 168, IWM 184, IWM 176, IWM 230, IWM 699d and IWM 342/2.

11. NPU 11, IWM 196, IWM 319, IWM 269.

12. 50,000 Miles with the Prince of Wales (1920), IWM 843.

13. IWM 26, IWM 32, IWM 37, IWM 41, IWM 42, IWM 45, NTB 328-1, IWM 508-36.

14. See IWM 65 for scenes of refugee women sewing at the British Army base depot in Baghdad. See also Arab men unloading stores from boats at Gaza and camels at Jaffa for the British Army, IWM 28.

15. IWM 501-8, IWM 501-13, IWM 502, IWM 508-67, IWM 564, IWM 1078, NTB 242-1. 
16. Messter Woche vol. 46 (1915), IWM 483-4.

17. Though see Nicholas Hiley, 'Making War: The British News Media and Government Control 1914-1916' (Open University, unpublished PhD thesis, 1985). On Hilton de Witt Girdwood and filming Indian troops in 1915, p. 386 and pp. 392-4. Also: Nicholas Reeves, Official British Film Propaganda during the First World War (London: Routledge, 1986), p. 150 and pp. 170-1; Nicholas Hiley, 'Hilton de Witt Girdwood and the Origins of British Official Filming', Historical Journal of Film, Radio and Television vol. 13 no. 2 (1993); Andrew D. Roberts, 'Africa on Film to 1940', History in Africa vol. 14 (1987), pp. 189-227; Philip Woods, 'Film Propaganda in India, 1914-23', Historical Journal of Film, Radio and Television vol. 15 no. 4 (1995), pp. 543-53; Pierre Sorlin, 'The French Newsreels of the First World War', Historical Journal of Film, Radio and Television vol. 25 no. 4 (2004), p. 509. Production files are internal records held in the Imperial War Museum's Film Archive documenting requests by programme-makers for archive footage to be used in television productions and, occasionally, commercial feature films. A typical file will contain correspondence, technical records and contracts covering the research, viewing, copying and licensing of archival footage.

18. The 1990 loan scheme catalogue included a section called 'Commonwealth Contribution'. Three of the five titles covered non-white forces of World War II. An expanded Commonwealth Contribution in the 2000 edition includes With the Indian Troops at the Front (1916). The museum also published two multimedia resource packs for teachers, devoted to the history of non-white forces in the World Wars: Together (1994), covering World War II and The Empire Needs Men! (1998), on World War I.

19. IWM Equality Strategy, 2007-10.

20. IWM 667.

21. With the Indian Troops at the Front (British Topical Committee for War Films), IWM 202-01/02.

22. The arrival of the Indian Corps appears in Our Empire's Fight for Freedom, IWM 440-02; Topical Budget 178-1, NTB 178-01; Pathe Animated Gazette (1915), NPU 1006.

23. Paul Fussell, The Great War and Modern Memory (Oxford: Oxford University Press, 1977), pp. 82-90.

24. IWM 1080a and MGH 3725.

25. Luke McKernan “"The Modern Elixir of Life”: Kinemacolor, Royalty and the Delhi Durbar', Film History vol. 21 (2009), pp. 122-36.

26. Joyce Collins, Doctor Brighton's Indian Patients (Brighton: Brighton Books, 1997). In April 2010, the Royal Pavilion, Brighton opened a permanent exhibition on the Indian war hospital.

27. David Omissi, Indian Voices of the Great War (London: Macmillan, 1999).

28. The Times, 25 October 1915, p. 7.

29. For the connection between South Asian and Scottish military identities, see Heather Streets, Martial Races and Masculinity in the British Army, 1857-1914 (Manchester: Manchester University Press, 2004).

30. David Killingray, 'All the King's Men? Blacks in the British Army in the First World War, 1914-1918', in Rainer Lotz and Ian Pegg (eds), Under the Imperial Carpet: Essays in Black History 1780-1950 (Crawley: Rabbit Press, 1986). Despite the desire to project racial homogeneity within the metropolitan army, Ireland and Scotland provided substantial numbers of recruits, a situation that continued up to and during World War I. Martial race 
theories held that the Celtic races made natural soldiers, although the Irish came to be viewed with some ambivalence; at once childlike, unruly and emotional: Keith Jeffrey, 'The Irish Military Tradition and the British Empire', in Keith Jeffrey (ed.), An Irish Empire?: Aspects of Ireland and the British Empire (Manchester: Manchester University Press, 1996), pp. 94-122; H. J. Hanham, 'Religion and Nationality in the Mid-Victorian Army', in M. R. D. Foot (ed.), War and Society (London: Elek, 1973), pp. 159-81.

31. Lionel Caplan, Warrior Gentlemen: 'Gurkhas' in the Western Imagination (Oxford: Berghahn Books, 1995), pp. 88-90, 93, 103; David Omissi, The Sepoy and the Raj: The Indian Army, 1860-1940 (London: Macmillan, 1998), pp. 28-9, 32-4.

32. Timothy H. Parsons, The African Rank-and-File: Social Implications of Colonial Military Service in the King's African Rifles, 1902-1964 (Oxford: James Currey, 1999), p. 54.

33. Manual of Military Law (London: HMSO, 1914), p. 471

34. Omissi, The Sepoy and the Raj, pp. 159-62.

35. Kathryn Castle, Britannia's Children: Reading Colonialism through Children's Books and Magazines (Manchester: Manchester University Press, 1996).

36. Richard Smith, Jamaican Volunteers in the First World War: Race, Masculinity and the Development of National Consciousness (Manchester: Manchester University Press, 2004), pp. 47-8.

37. Battle of the Ancre and the Advance of the Tanks (British Topical Committee for War Films, 1917), IWM 116; British Topical Committee for War Films, 1916.

38. Major A. B. Ellis, The History of the First West India Regiment (London: Chapman \& Hall, 1885), pp. 13-15.

39. The literature on this subject is now extensive, but influential early studies include E. J. Leed, No Man's Land: Combat and Identity in World War I (New York: Cambridge University Press, 1979); E. Showalter, The Female Malady: Women, Madness and English Culture, 1830-1980 (London: Virago, 1987).

40. R. A. Soloway, Degeneracy and Degeneration: Eugenics and the Declining Birthrate in Twentieth Century Britain (Chapel Hill: University of North Carolina Press, 1990); D. Feldman, 'The Importance of Being English: Jewish Immigration and the Decay of Liberal England', in D. Feldman and G. Stedman Jones (eds), Metropolis London: Histories and Representations since 1800 (London: Routledge, 1989).

41. Smith, Jamaican Volunteers in the First World War.

42. South African Native Labour Contingent: Somewhere in France (Topical Film Company, November 1917), IWM 413.

43. National Archives WO32/5094 WO Minute AAG to AG 23 January 1917.

44. Omissi, Indian Voices of the Great War, p. xxi.

45. Daniel Tetteh Osabu-Kle, Compatible Cultural Democracy: The Key to Development in Africa (Peterborough, ON: Broadview Press, 2000), pp. 44-8.

46. Topical Film Company, 1917, IWM 130-05+6

47. Christopher Pugsley, Te Hokowhitu a Tu: The Maori Pioneer Battalion in the First World War (Auckland: Reed, 1995). James Cowan, The Maoris in the Great War: A History of the New Zealand Native Contingent and Pioneer Battalion: Gallipoli, 1915, France and Flanders, 1916-1918 (Auckland: Whitcombe \& Tombs, 1926).

48. Marilyn Lake, 'Mission Impossible: How Men Gave Birth to the Australian Nation Nationalism, Gender and Other Seminal Acts', Gender \& History, vol. 43 (1992), pp. 305-22.

49. Visit of the Hon. W. F. Massey and Sir J. Ward to the Western Front 30 June-2 July 1918, IWM 269. 
50. Robert H. MacDonald, Sons of the Empire: The Frontier and the Boy Scout Movement, 1890-1918 (Toronto: University of Toronto Press, 1993), pp. 8-13.

51. Hodges, Kariakor.

52. Edward Paice, Tip and Run: The Untold Tragedy of the Great War in Africa (London: Weidenfeld and Nicolson, 2007).

53. IWM 84.

54. Malcolm Page, KAR: A History of the King's African Rifles (London: Leo Cooper, 1998); Parsons, The African Rank-and-file.

55. Cherry Kearton, Adventures with Animals and Men (London: Longmans, Green \& Co., 1935), pp. 230-8.

56. Ibid., p. 245.

57. Ibid., pp. 250-1.

58. Deir El Belah (Topical Film Company, 1918), IWM 10.

59. Institute of Commonwealth Studies WIC/3/BWIR War Diary, 1st Battalion of the British West Indies Regiment, 1915-1919, pp. 75-8.

60. A. A. Cipriani, Twenty-five Years After: The British West Indies Regiment in the Great War 1914-1918 (Port of Spain: Trinidad Publishing Co., 1940), p. 20. 